SIRS,

You have thought fit to entrust the reviewing of my Propertius to one who has himself published an edition of that poet, and with whose interpretations I have so often bad to express disagreement. I am not imputing any unworthy motive to Professor Butler when I ask whether, in such circumstances, it would be possible for anyone to view my work with an open mind.

I cannot. of course, defend the passage in my Preface which he very properly condemns, though I could explain, if it were worth while, how it came to remain uncorrected. But I wish to point out that the dates of the MSS. have no bearing whatever on the prime object of my work, namely the restoration of unbroken continuity to the text. Of this Professor Butler takes hardly any notice. He merely complains of the number of my transpositions-as well might he blame the restorer of the Portland Vase for making so many adjustments-and mentions as the worst example (he gives no other) the placing of $3 \cdot 22 \cdot 37-8$, where he him- self declares these to be 'impossible,' to follow 3. 16. 6 , where they are quite appropriate. I have made a practice of giving reasons for $\mathrm{my}$ transpositions : not one of these does he attempt to confute. The new interpretations of many obscure passages are passed by without a word of comment, as also are the original views I hold as to Propertius' extreme youth, his illhealth, the real cause of his twelve months' banishment, the reason of his indignation against Cynthia in 2. 20, his attitude towards Octavian, etc. Had my edition appeared before his, Professor Butler would have been spared many of his perplexities.

$\mathrm{He}$ cites examples of what he ex cathedra asserts to be my 'failings.' I admit two only. For others I have the authority of Postgate.

I can only conclude that Professor Butler was unable to spare time for any but a cursory survey of my work. As to his opinion of the translation, de gustibus. . . .

Yours faithfully,

SEYMOUR G. TREMENHEERE.

April 1, 1932.

\title{
SUMMARIES OF PERIODICALS
}

\section{PHILOLOGISCHE WOCHENSCHRIFT.}

(DECEMBER, 193I-MARCH, I932.)

Greek Literature.-J. Martin, Symposion. Die Geschichte einer literarischen Form [Paderborn, I93I, Schöningh. Pp. 320] (Geffcken). The first general survey of this type of literary composition ; fills a long-felt gap with desirable thoroughness.-K. Holzinger, Erklärungen umstrittener Stellen des Aristophanes. S.B. d. Wien. Ak. d. Wiss. Phil.-hist. Kl. Bd. 208, 5 [Vienna, 1928, Hölder-Pichler-Tempsky. Pp. 76] (Wüst). Noteworthy contribution to the explanation of six disputed passages, four of them from the Wasps.-M. Pohlenz, Die griechische Tragödie. Also Erï̈uterungen [Leipzig, 1930, Teubner. Pp. vi +542 . Pp. 148] (Körte). Reviewer considers this the best general survey of Greek Tragedy that we possess. All concerned with the Attic tragedians will have to read it carefully.E. Cahen, Callimaque et son auvre poétique. Also Les hymnes de Callimaque, commentaire explicatif et critique. Bibliothèque des écoles françaises d'Athènes et de Rome, 134, 134 bis [1929, Pp. 655. 19.30, Pp. 283] (Kalinka). Does not contain much new ; but so useful as a conscientious and critical collection of results of previous research that no one interested in Callimachus should overlook it.-Barbara C. J. Timmer, Megasthenes en de indische Maatschappij [Amsterdam, 1930. Pp. 323] (Kraemer). Attractive and instructive. Conscientious collection of all the relevant material and a real advance in the problems connected with Megasthenes. Deserves many readers.-A. Weizsäcker, Untersuchungen über Plutarchs biographische Technik [Berlin, 1931, Weidmann. Pp iv + 122]
(Schönemann). Carefully thought out and very valuable. But reviewer disagrees on several points.

LATIN LITERATURE.-K. Witte, Die Geschichte der römischen Dichtung im Zeitalter des Augustus. Zweiter Teil: Horaz. Erster Band : Horazens Sermonendichtung [Erlangen, 193I, Selbstverlag des Verfassers. Pp. 288] (Seel). W.'s book indicates new and exceedingly fruitful possibilities in literary criticism. He makes an understanding of Horace's poetry depend on the recognition of three things, (1) transitional links, (2) references, (3) quantitative balance of sections.- N. Terzaghi, Orazio [Rome, I930, Formaggini. Pp. 89] (Hosius). A sketch in profile, full of light and warmth. Does not pretend to be a full biography. Reviewer raises a few doubtful points.-B. Edmar, Studien zu den Epistulae ad Caesarem senem de re publica [Lund, 1931, Ohlsson. Pp. 177] (Klotz). Most detailed linguistic commentary on the Epistulae ad Caesarem supports Sallustian authorship. Reviewer hopes the controversy will now cease.

History.-E. Derenne, Les procès dimpieté intentés aux philosophes à Athènes au $V^{\text {me }}$ et aus $I V^{\text {me }}$ siecles avant J.-C. [Liège, I930, Vaillant-Carmanne. Pp. 27I] (Nestle). Reveals throughout a thorough study of the sources and excellent knowledge of modern literature on the subject. - U. Wilcken, Alexander der Grosse [Leipzig, I93I, Quelle u. Meyer. Pp. ix +316] (Lenschau). Ripe fruit of a life devoted to study of Alexander. Will long remain the foundation of research in this field.

Religion AND Mythology.-F. Altheim, Terra Mater. Untersuchungen zur altital- 